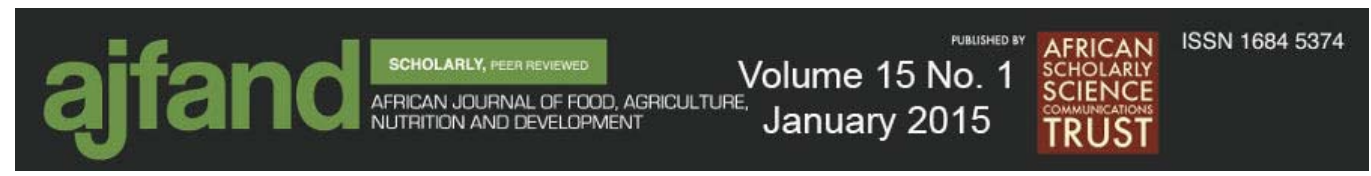

\title{
BIOCONTROL OF POTATO WILT BY SELECTIVE RHIZOSPHERIC AND ENDOPHYTIC BACTERIA ASSOCIATED WITH POTATO PLANT
}

\author{
Rado $\mathbf{R}^{1^{*}}$, Andrianarisoa $\mathbf{B}^{2}$, Ravelomanantsoa $\mathrm{S}^{3}$, \\ Rakotoarimanga $N^{1}$, Rahetlah $V^{4}$, Fienena $F_{R}^{1}$ and $O$ Andriambeloson ${ }^{1}$
}

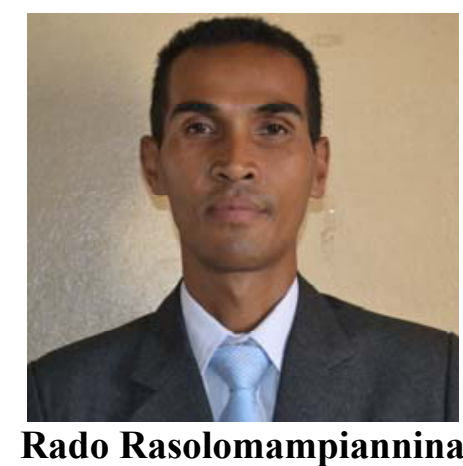

*Corresponding author mail: mampionina@yahoo.fr

${ }^{1}$ Centre National de Recherche sur l'Environnement (CNRE), Antananarivo, Madagascar

${ }^{2}$ Laboratoire de Biotechnologie-Microbiologie, Département de Biochimie Fondamentale et Appliquée, Faculté des Sciences, Université d'Antananarivo, Madagascar

${ }^{3}$ CIRAD-3P, Pôle de Protection des Plantes, UMR PVBMT, Saint-Pierre, La Réunion, France

4(FIFAMANOR) Centre de Développement Rural et de Recherche Appliquée, Antsirabe, Madagascar 


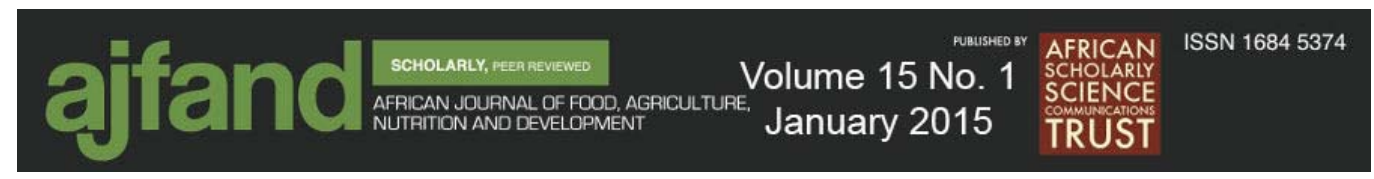

ABSTRACT

Ralstonia solanacearum is the causative agent of wilt disease in plants, which constitutes a severe problem to agricultural crops, particularly for potato production in Madagascar. The present study focuses on the isolation, in vitro and in vivo assays of potential rhizospheric and endophytic bacteria associated with healthy potato plant, capable to inhibit the growth of Ralstonia solanacearum for controlling potato bacterial wilt. A total of 77 bacteria strains were isolated from six soil rhizospheric samples and six vegetal material samples of healthy potatoes in the district of Antsirabe II. Forty of them were telluric actinomycetes, 25 were endophytic actinomycetes and 12 were fluorescent Pseudomonas spp. An additional 30 phytopathogenic isolates were obtained from six rhizopsheric soil samples of diseased potatoes. Morphological, cultural, biochemical characterization and molecular identification with the Ralstonia solanacearum specific primers 759/760 revealed that 24 of the pathogenic isolates belong to the Ralstonia solanacearum species, biovar two; the causal agent of potato bacterial wilt. Isolates from healthy plants were, then, examined in vitro and in vivo for their antagonistic activity against Ralstonia solanacearum strain for their potential to improve potato plant growth. In vitro antagonism of actinomycete and Pseudomonas isolates against Ralstonia solanacearum development was performed using agar diffusion technique, while in vivo tests were conducted under greenhouse conditions. Ten antagonistic strains including two Pseudomonas, four telluric actinomycetes, and four endophytic actinomycetes inhibited the tested Ralstonia strain. Four strains, E7, E13 (endophytic actinomycete from root potatoes), S25 (telluric actinomycetes) and P7 (fluorescent Pseudomonas), showed high antagonistic activity against the pathogen with zones of inhibition from 23 to $40 \mathrm{~mm}$. Of the fours strains tested in greenhouse, E7 significantly reduced $(\mathrm{p}<0.05)$ the percentage of Ralstonia solanacearum that infected plants by $72.04 \%$. The isolates E13 and S25 have also been demonstrated to improve plant growth by increase of plant height to $44.63 \%$ and $44.84 \%$, fresh weight to $68.75 \%$ and $75.85 \%$ and dry weight to $86.17 \%$ and $115.42 \%$, respectively compared with non-treated control. Morphological and cultural characterization of these three active isolates showed that they belong to the genus Streptomyces. The antagonism of these isolates against Ralstonia solanacearum according to in vitro and in vivo tests results, along with their high efficiency as regards the improvement of plant development, suggests that these three actinomycete strains E7, E13 and S25 could be useful for biocontrol of potato bacterial wilt.

Key words: Potato, Ralstonia, Actinomycetes, Pseudomonas, Biocontrol 


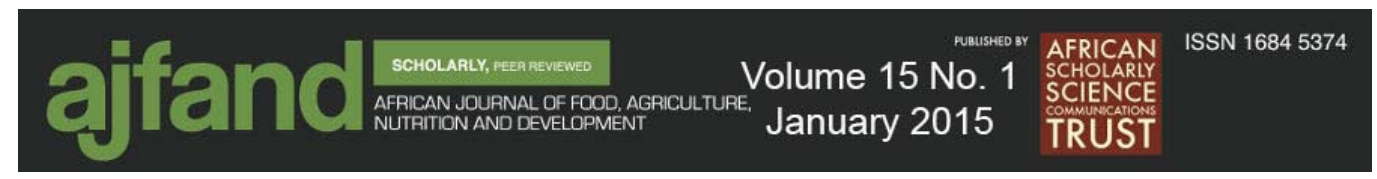

\section{INTRODUCTION}

Bacterial wilt caused by the various subgroups of the plant pathogenic bacterium Ralstonia solanacearum is an important disease of crop plants in tropical, subtropical and warm temperate regions. This pathogen has a wide host range and infects more than 450 monocotyledonous and dicotyledonous plant species belonging to 54 botanical families [1].

Bacterial wilt of potato (Solanum tuberosum L.) is a serious constraint to potato production and exportation in small-scale farms in the Vakinankaratra region, the main potato-farming region in Madagascar. The disease occurs in almost all potato-growing areas including paddy rice fields and causes severe losses of potato yield and quality specifically during the warm and rainy season. Visible symptoms are foliage wilting and stunting which could be followed by tubers rotting showing a vascular ring or a grey-brown discoloration of vascular tissues.

Infested soil and infected potato seed tubers and plants are the main sources of disease inoculum but contaminated surface water used for irrigation and contaminated tools may also spread the disease. As Ralstonia solanacearum strains can survive in soil and in the rooting system of many hosts including weeds, soil fumigation and crop rotation alone cannot control bacterial wilt. The use of resistant varieties of potato has significantly reduced bacterial wilt incidence but resistance is strain-specific and varies with temperature, soil moisture and other by environmental conditions. Many studies report that biological control is a promising alternative strategy for the integrated control of bacterial plant diseases. Therefore, the effectiveness of microbial antagonists against Ralstonia solanacearum growth has been reported in the present work. Among these antagonistic microorganisms, actinomycetes are well-known and classified among the most active [2].

In addition, some Pseudomonas spp. have been shown to initiate the expression of plant defense mechanisms [3].

The bioprotection conferred by these microbial agents may be based on competition for essential nutrients, antagonistic activity against the growth of pathogens through the production of antibiotics or enzymes, or their ability to stimulate defense systems in the plant host. In the wild, the rhizosphere of healthy plants includes Pseudomonas and/or actinomycetes capable of ensuring the defense of the plants against bacterial agents and/or phytopathogenic fungi.

Thus, the objective of this study was to identify possible biocontrol strains against bacterial wilt by isolating bacteria (actinomycetes and Pseudomonas strains) from healthy potato plants, evaluating in vitro their potential antagonism against isolated and characterized Ralstonia solanacearum from infected soil, and testing their plant growth potential under greenhouse conditions. 


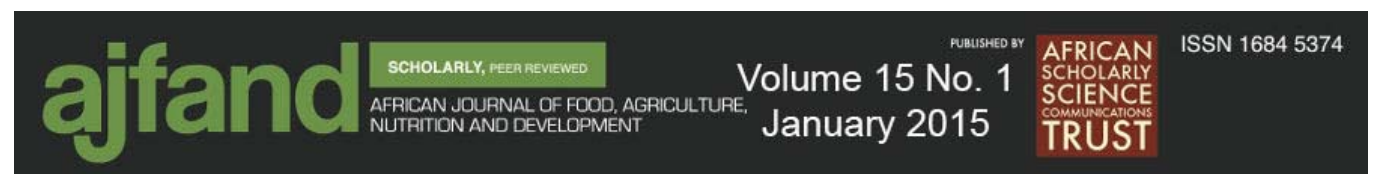

\section{MATERIALS AND METHODS}

\section{Soil and plant sampling}

Soil samples were collected in the rhizosphere of two potato varieties (Meva and Diamondra) in two sites (Antanetibe and Ankotrabe ambony) of the district of Antsirabe II in Vakinankaratra region, the main production region of potato. For telluric strains isolation, soil samples were taken under healthy potato plants. For endophytic actinomycetes isolation, three samples of healthy plant material (leaves, stems and roots) were used, and for phytopathogenic bacteria isolation, soil samples were collected under diseased potato plants.

Twelve soil samples were collected from these two sites with three samples per site. $100 \mathrm{~g}$ of each sample were collected and placed in sterile plastic bags. Samples were then maintained at $+4^{\circ} \mathrm{C}$ until use.

\section{Phytopathogenic bacteria isolation and identification}

The serial dilution method was applied to isolate Ralstonia solanacearum from soil. One $\mathrm{g}$ of soil sample was added to $9 \mathrm{ml}$ of sterile distilled water. Soil suspension was shaken in rotary shaker at $160 \mathrm{rpm}$ until homogenization and suspensions were plated in Kelman's triphenyl tetrazolium chloride (TZC) agar medium [4] supplemented with one percent of yeast extract. Plates were incubated for $48 \mathrm{~h}$ at $28^{\circ} \mathrm{C}$. Bacterial colonies developing the typical irregular mucoid of Ralstonia solanacearum morphotype were subcultured on fresh TZC medium for further purification. Pure isolates were, subjected to phenotypic identification [5], biovar determination [6] and molecular characterization.

\section{PCR amplification for species confirmation}

Genomic DNA of isolates was extracted using DNeasy Blood \& Tissue Kit (Qiagen, Cat. No. 69504) according to the manufacturer's instructions. A singleplex PCR with the Ralstonia solanacearum - specific primers 759/760 (5' GTC GCC GTC AAC TCA CTT TCC 3' and 5' GTC GCC GTC AGC AAT GCG GAA TCG 3') [7] was carried out in a $25 \mu \mathrm{l}$ reaction volume with the following reagents: $\sim 2 \mathrm{ng} / \mu \mathrm{l}$ of template DNA, $0.625 \mathrm{U}$ of GoTaq Flexi, 4 pmoles of each primer, $1.5 \mathrm{mM} \mathrm{MgCl} 2,0.2 \mathrm{mM}$ dNTP (Promega) and $1 \mathrm{X}$ supplied amplification buffer PCR. The reaction was performed at the following steps: a denaturation step at $96^{\circ} \mathrm{C}$ for $5 \mathrm{~min}, 30$ cycles at $94^{\circ} \mathrm{C}$ for $15 \mathrm{~s}$, $29^{\circ} \mathrm{C}$ for $30 \mathrm{~s}$ and $72^{\circ} \mathrm{C}$ for $30 \mathrm{~s}$, followed by a final extension at $72^{\circ} \mathrm{C}$ for $10 \mathrm{~min}$. The expected 280-bp reference PCR products from the ribosomal DNA specific of Ralstonia solanacearum species were revealed by electrophoresis through $1.5 \%$ agarose gel in 50X TAE (Tris-acetate-EDTA) buffer stained with ethidium bromide and gels were imaged in GeneSnap (a Syngene Bioimaging System, Syngene) with UV transilluminator at a wavelength of $302 \mathrm{~nm}$ [7].

\section{Isolation of antagonistic isolates}

Fluorescent Pseudomonas spp. were isolated and counted using the King et al. technique [8]. This technique is based on the observation of pyoverdine under ultraviolet light at $254 \mathrm{~nm}$, a fluorescent pigment which represents the majority of siderophores produced by these bacteria. For this, $1 \mathrm{~g}$ of each soil sample is weighed 


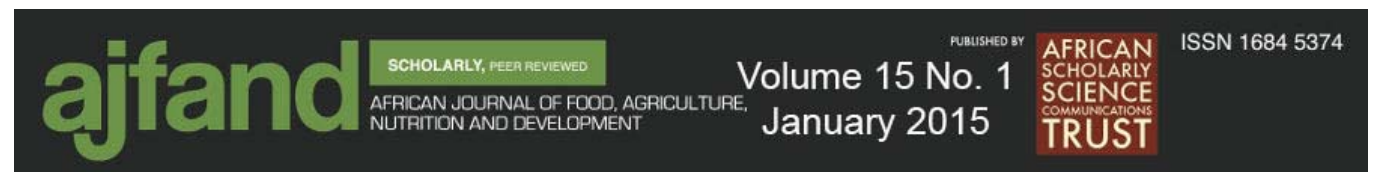

and then serial dilutions (with $9 \mathrm{ml}$ of PBS) were performed. Inoculation was done on the surface; inoculated plates were incubated at $28^{\circ} \mathrm{C}$. All fluorescent colonies are counted and collected using a pre-sterilized "toothpick" and then subcultured into new plates containing King B medium.

Endophytic actinomycetes from leaves, stems and roots of healthy potato plant were isolated according to the method described by Fischer et al. [9].

Plant samples were washed in water and surface sterilized in ethanol $70 \%$ for $30 \mathrm{~s}$. Then, they were treated with sodium hypochlorite $(3 \%)$ for 3 min followed by three successive washings in sterile water. Each sample was divided into pieces of ca. $1 \mathrm{~cm}$ and pieces were aseptically transferred into petri dishes containing Starch Casein Agar medium (SCA) [10].

Actinomycete isolation from rhizospheric soil samples was performed by soil dilution plating technique on Starch Casein agar [11].

Selected colonies of actinomycetes (rough, chalky) were subcultured by incubating at $30^{\circ} \mathrm{C}$ and maintained on Waksman agar slants. Cultures were then kept at room temperature and $4^{\circ} \mathrm{C}$ or $-20^{\circ} \mathrm{C}$. Strains were subcultured to fresh media every two months.

\section{In vitro antagonism assay}

Antagonistic activity of actinomycete and Pseudomonas isolates against the most pathogenic Ralstonia solanacearum strain R15 (pathogenicity assay not shown) was tested according to Almoneafy's method [12].

A culture of Ralstonia solanacearum was grown overnight in nutrient broth and then centrifuged. The cell pellet was suspended in sterilized saline solution $(0.85 \% \mathrm{NaCl})$. Ten $\mathrm{ml}$ of Ralstonia suspension $\left(10^{8} \mathrm{CFU} / \mathrm{ml}\right)$ were mixed with 11 of melted YPGA medium added with $5 \mathrm{ml}$ of 2, 3, 5-triphenyl tetrazolium chloride (TZC), poured into sterile plates and allowed to solidify.

Thereafter, tested isolates were transferred to the surface of YPGA medium with sterile toothpicks and incubated at $28^{\circ} \mathrm{C}$ for four days for actinomycetes and two days for Pseudomonas. Four replicates were done under completely randomized design (CRD) for this assay. The inhibition of Ralstonia growth was revealed by the presence of clear halos without pinkish coloration around the tested isolates.

\section{In planta assay}

Four isolates were selected for further test based on their in vitro activity against Ralstonia solanacearum. Glasshouse experimentation was used to test their ability to suppress potato bacterial wilt. Inocula were prepared by growing tested antagonistic isolates on SCA (actinomycetes) and on King B media (fluorescent Pseudomonas). Plates were then incubated at $30^{\circ} \mathrm{C}$ for two weeks for actinomycetes and two days for Pseudomonas. 


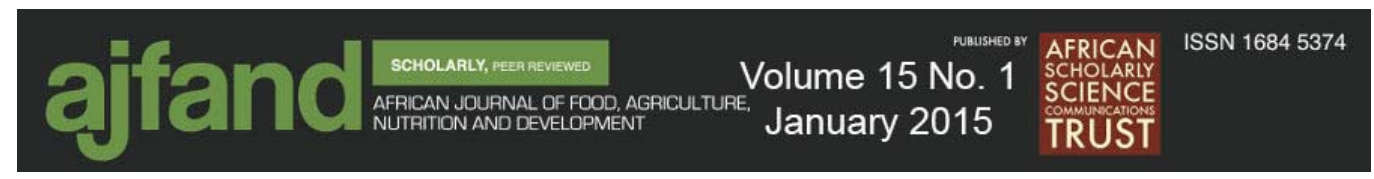

The potato variety "Spunta" which is highly susceptible to Ralstonia solanacearum, was used in this assay. Cuttings were sterilized in sodium hypochlorite solution $2 \%$ for 2 min and washed thoroughly in sterile water. Samples were, then, soaked overnight in the bacterial suspension $\left(10^{8} \mathrm{CFU} / \mathrm{ml}\right)$ and cuttings immersed in sterile saline served as controls. Thereafter, potatoes inoculated with bacteria were planted into pots containing sterile soil mixed with peat and infected with the most pathogenic Ralstonia solanacearum strain (R15). The pots were placed in a greenhouse and maintained at $30^{\circ} \mathrm{C}$ and, $60 \%$ humidity in order to favor disease development. Furthermore, two control treatments were prepared: control one $(\mathrm{C} 1)$ where cuttings were treated with pathogen only and control two $(\mathrm{C} 2)$ where cuttings were planted without pathogen or tested antagonistic isolates. Every treatment was run in four replicates with five plants in each pot. All treatments were distributed in a randomized position to avoid any positional effect on plant growth.

The treated plants were monitored for disease development for 30 days and disease index was rated using the following scale: DI 0: no wilting; DI 1: 1-25\% wilt symptom; DI 2: 26-50\% wilt symptom; DI 3: $51-75 \%$ wilt symptom; DI 4: $76-100 \%$ wilt symptom or dead [13].

The disease incidence and biocontrol efficacy were estimated accordingly [14]:

Disease incidence $(\%)=[$ (Disease index $x$ number of diseased plant in this index $) /($ Total number of plants investigated $\mathrm{x}$ the highest disease index $)] \mathrm{x} 100$.

Biocontrol efficacy $(\%)=[($ Disease incidence of control - Disease incidence of antagonist-treated group)/(Disease incidence of control)] x 100.

\section{Plant growth parameters evaluation}

After two months of treatment, the effect of antagonistic isolates on plant growth was assessed in terms of plant height, fresh and dry biomass weight. Dry biomass was obtained by drying plant samples at $60^{\circ} \mathrm{C}$ for three days. Moreover, growth promotion efficacy (GPE) was calculated to show the relative effect of antagonistic isolates on plant growth compared with the two control treatments by the following formula [12]: Growth promotion efficacy $(\%)=[$ (Growth parameter in antagonist-treated group Growth parameter in control group)/(Growth parameter in control group)] x 100 .

\section{Characterization of active bacterial strains}

Three actinomycetes isolates that showed high antagonistic activity and enhanced plant growth in greenhouse were characterized morphologically following the directions given by the International Streptomyces Project (ISP) [15] and Bergey's Manual of Systematic Bacteriology [16]. Cultural characteristics of pure isolates in various media: ISP2, ISP4, ISP5, Starch Casein Agar were recorded after incubation for seven to 21 days at $30^{\circ} \mathrm{C}$. Morphological observations were made using a light microscope [15].

\section{Statistical analysis}

The GenStat software was used for data analysis [17]. Mean comparisons were conducted using a Least Significant Difference (LSD) test $(\mathrm{P}<0: 05)$. 


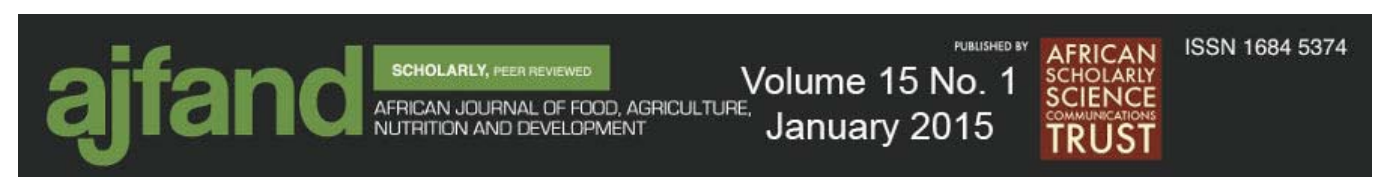

\section{RESULTS}

\section{Isolation and characterization of Ralstonia solanacearum strains}

Thirty strains were isolated from six soil rhizospheric samples under diseased potato plants based on morphological and cultural characteristics. Among these, 24 strains not showing fluorescent pigment production were subjected to biochemical characterization including biovar determination. The results given in Table 1 show that all isolates have catalase and oxidase enzymes. They use disaccharides including cellobiose, maltose and lactose but not sugar alcohols. On the basis of biochemical tests, strains are grouped into biovar two and PCR results show that the 759/760 primer set amplified a 280-bp fragment for all strains, supporting their identity as Ralstonia solanacearum (Figure 1).

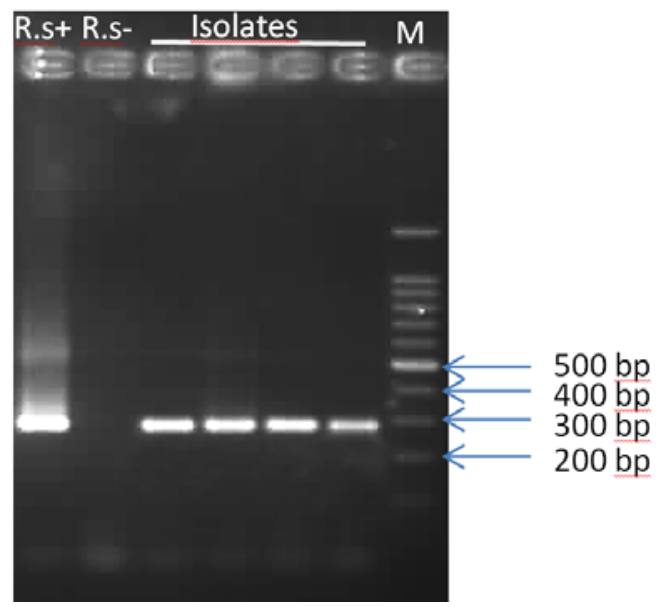

Figure 1: DNA bands of Ralstonia solanacearum (280pb) in agarose gel after PCR amplification M: $1 \mathrm{~kb}$ sizing ladder; R.s+: Ralstonia solanacearum reference strain (GMI1000), R.s-: negative control (no template)

\section{Isolation and in vitro screening of antagonistic isolates}

A total of 77 strains were obtained from two varieties of potato vegetal material and its rhizospheric soils (40 telluric actinomycetes, 25 endophytic actinomycetes and 12 fluorescent Pseudomonas spp.). Among 77 isolates screened, ten isolates P7, P10, S18, S19, S23, S25, E4, E7, E12 and E13 inhibited Ralstonia solanacearum strain development. Out of these, four isolates E7, S25, P7 and E13 gave a large zone inhibition with 40,34, 26 and $23 \mathrm{~mm}$ diameter respectively; while the remaining isolates presented an inhibition zone from 9 to $20 \mathrm{~mm}$ of diameter (Figure 2). 

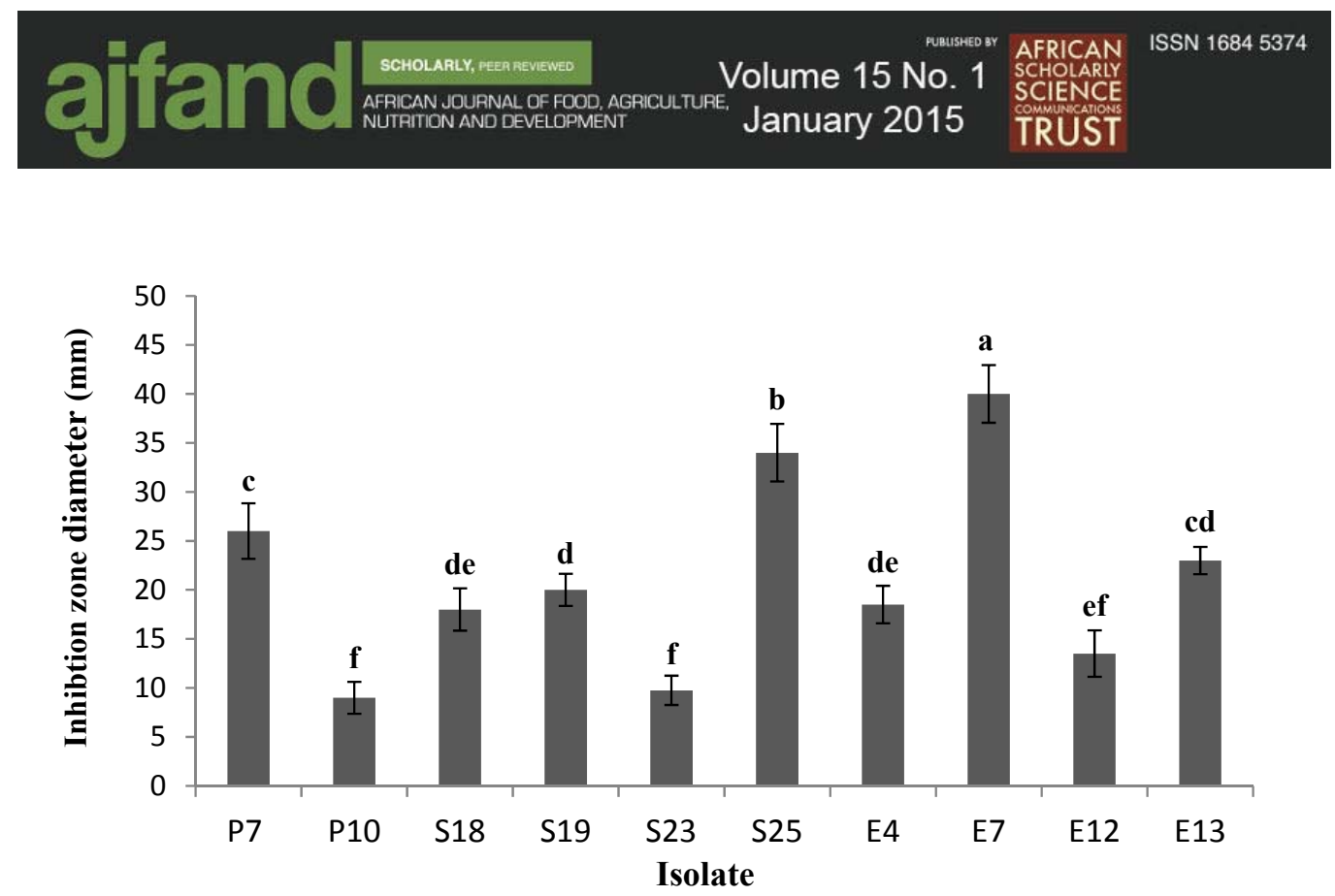

Figure 2: Diameter of inhibition zone $(\mathrm{mm})$ of ten antagonistic bacterial strains on Ralstonia solanacearum E: Endophytic actinomycetes; S: Telluric actinomycetes; P: Fluorescent Pseudomonas

\section{In vivo evaluation of potential antagonists}

Antagonistic bacterial strains showed significant differences in their ability to suppress potato bacterial wilt. Isolate E7 showed the lowest value of wilt incidence as well as the highest value of biocontrol efficacy against Ralstonia solanacearum with 20.08 and $72.04 \%$, respectively. However, isolate P7 exhibited the highest disease incidence and the lowest value of biocontrol efficacy with 68.98 and $4.53 \%$, respectively. Isolates E13 and S25 sustained significantly lower disease incidence and biocontrol efficacy compared with control (Table 2).

Indeed, significant differences among treatments regarding plant height and biomass were noted. The highest values were recorded for plants treated with the isolates E13 and S25 for all measured parameters compared to the control and other treatments (Table 3). The weights of fresh shoot biomass were 8.75 and $9.118 \mathrm{~g}$, respectively with a corresponding GPE 68.75 and $75.85 \%$. Those of dry shoot biomass were, however, 3.64 and $3.15 \mathrm{~g}$ with a GPE 115.42 and $86.7 \%$, respectively. Otherwise, plant heights were 60.66 and $60.75 \mathrm{~cm}$ for treatments with E13 and S25. Their GPE were 44.63 and $44.84 \%$, respectively.

\section{Cultural and morphological characterization of selected isolates}

The three isolates E7, E13 and S25 grew on a range of agar media showing morphology typical of Streptomycetes. The color of the substrate mycelium and aerial spore mass varied (brown and white for the isolates E7 and S25, red for the isolate E13). The isolate E13 produced diffusible pigment on SCA agar media. Melanin was produced on peptone-yeast extract agar (ISP6) and ISP7 agar. 


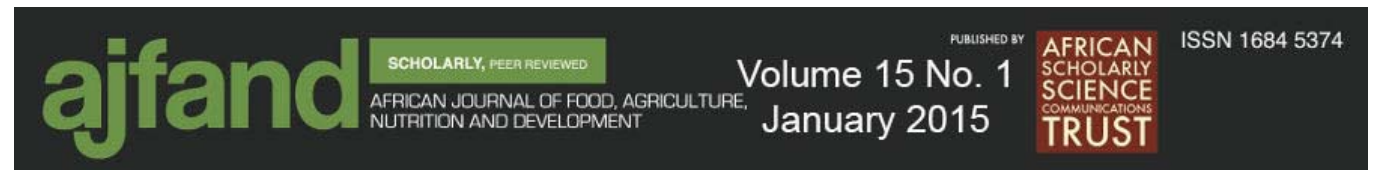

Aerial hyphae of all isolates differentiated into long spiral chains of cylindrical spores. The vegetative hyphae of all isolates were branched but not fragmented. Verticils were not detected.

\section{DISCUSSION}

From two infected potato fields in Antsirabe II district in the Vakinankaratra region of Madagascar, 30 phytopathogenic strains of Ralstonia solanacearum were isolated from six soil samples. Polymerase chain reaction (PCR) amplification with specific primers confirmed that the isolates were Ralstonia solanacearum strains and biochemical test showed that they belong to the biovar two. Thus, our result is different from those reported by some authors $[18,19]$ in a survey of potato plants for bacterial wilt in Madagascar, where Ralstonia solanacearum was found to belong to the biovar one. To our knowledge, this is the first record of Ralstonia solanacearum strain, biovar two in Madagascar. However, further investigation is necessary for origin confirmation and phylotype classification.

An Additional, 77 strains for biocontrol test were isolated from healthy plants and their rhizospheric soils. Among these, antagonism assays showed that ten isolates displayed remarkable antagonistic activity against Ralstonia solanacearum and the isolates E7, E13, S25 and P7 exhibited the highest inhibition effect. Some previous studies reported that actinomycetes and fluorescent Pseudomonas spp. showed antagonistic activity against phytopathogenic bacteria and fungi [20,21,22]. This antagonistic mechanism may be due to antibiosis or production of siderophores or both [23]. Moreover, endophytic actinomycetes were found to produce at least three kinds of antagonistic substances in plant tissues including antibiotics, enzymes and siderophores [24]. The inhibition of pathogen bacteria development could be due to the emission of volatile secondary metabolites secreted by actinomycetes.

In greenhouse experimentation, the application of two endophytic actinomycete strains and one telluric actinomycete on potato plants induced good reduction of disease severity of potato bacterial wilt. This reduction was significantly higher than observed with the Pseudomonas isolate. Furthermore, plants treated with these three strains showed high values of plant height and biomass (fresh and dry weight) compared with the control treatment. Previous work has demonstrated that root-associated bacteria are promising tools to control soil-borne pathogens and to enhance plant growth [25]. This is in agreement with our study which shows that E7, E13 (endophytic actinomycetes isolated from potato roots) are active against Ralstonia solanacearum and significantly improve plant growth.

Plant growth promotion may be due to the production of plant growth promoters by efficient strains. Several species of Streptomyces secrete indole-three-acetic acid (IAA) when fed with L-tryptophan and improve plant growth [26]. It has been also demonstrated that some endophytic actinomycetes produce plant growth promoters with auxin-like activity; these compounds were shown to accelerate the formation of plant adventitious roots [27]. 


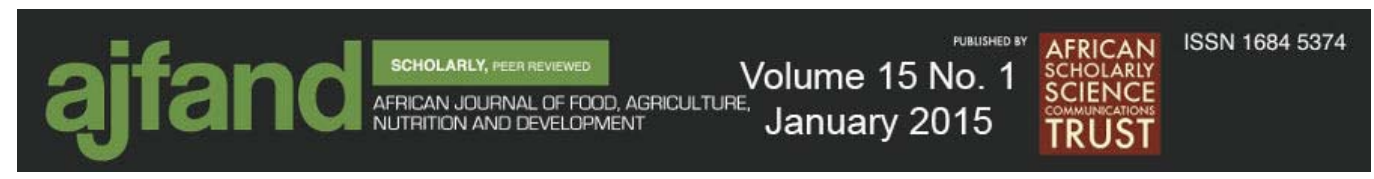

One isolate of Pseudomonas (P7) showed high antagonism in vitro but resulted in the lowest disease suppression in planta. A previous study demonstrated that fluorescent Pseudomonas may succeed as a biocontrol agent in vitro or under controlled conditions but fail under pot experiments and field conditions [28]. This could be explained by the fact that the development of the biocontrol agents is influenced by environmental factors such as unfavorable conditions for growth and competition with other microorganisms.

Cultural and morphological characterization of the three active isolates using a light microscopy showed that they belong to the genus Streptomyces. Branching filaments, abundant aerial mycelia, and long chains of small rectiflexible spores are visible, all of which are characteristic of Streptomyces sp. [29]. These isolates showed opaque, rough, nonspreading colonies which adhere to agar medium as described in Bergey's Manual of Determinative Bacteriology [16, 30]. Morphological examination indicated that the three isolates belong to the genus Streptomyces.

In conclusion, this study reports for the first time the antagonistic activity of actinomycetes and Pseudomonas strains against Ralstonia solanacearum, the causal agent potato bacterial wilt in Madagascar. Therefore, further work will be needed to investigate the mode of action of the strains that showed high antagonistic activity and high performance to enhance plant growth (E7, E13 and S25) and to confirm their effectiveness under natural conditions.

\section{ACKNOWLEDGEMENT}

This work was funded by PARRUR and SCAC of France Embassy. We would like to thank the whole Raltsonia project team: FIFAMANOR, CNRE, CIRAD La Réunion, Biochemistry and Entomology Departments of the University of Antananarivo. We are also grateful to Dr Leah Blasiak and Dr Liva Rakotondraibe for helping to revise the paper. 


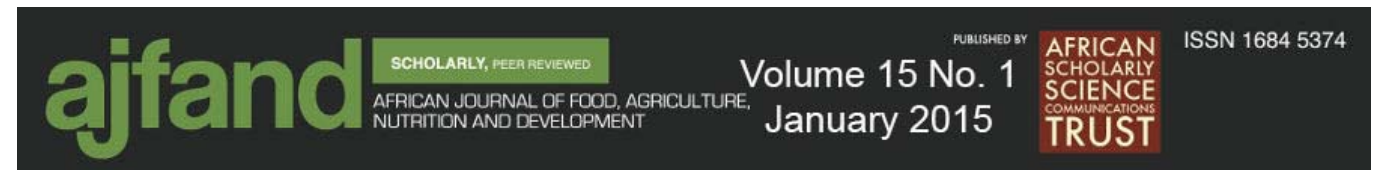

Table 1: Identification of isolates based on biochemical characterization and biovar determination

\begin{tabular}{|c|c|c|c|c|c|c|c|c|}
\hline \multirow[t]{3}{*}{ Isolate } & \multicolumn{2}{|c|}{ Biochemical test } & \multicolumn{6}{|c|}{ Biovar determination } \\
\hline & \multicolumn{2}{|c|}{ Character } & \multicolumn{6}{|c|}{ Disaccharides and sugar alcohols } \\
\hline & Catalase & Oxydase & Mal & Lac & $\mathrm{Cel}$ & Dul & Man & Sor \\
\hline \multicolumn{9}{|l|}{ R1-R2-R3-R4-R5-R6-R7- } \\
\hline \multicolumn{9}{|l|}{ R8- R9- R12-R13-R14 } \\
\hline R15-R17-R18-R20-R21- & + & + & + & + & + & - & - & - \\
\hline \multicolumn{9}{|l|}{ R22-R23-R25-R26-R27- } \\
\hline R28-R30 & & & & & & & & \\
\hline
\end{tabular}

Mal: Maltose; Lac: Lactose; Cel: Cellobiose; Duc: Dulcitol; Man: Mannitol; Sor: Sorbitol; R: Ralstonia strains

+ indicates presence and - indicates absence of the character

Table 2: Disease incidence and biocontrol efficacy of treatments with four isolates E7, E13, S25 and P7 against Raltsonia solanacearum

\begin{tabular}{lcc}
\hline Treatment & Disease incidence (\%) & Biocontrol efficacy (\%) \\
\hline E7+R.s & $20.08 \pm 1.46^{\mathrm{c}}$ & $72.04 \pm 1.14^{\mathrm{a}}$ \\
E13+R.s & $50.37 \pm 1.62^{\mathrm{b}}$ & $30.60 \pm 1.56^{\mathrm{c}}$ \\
S25+R.s & $47.26 \pm 0.99^{\mathrm{b}}$ & $34.41 \pm 2.13^{\mathrm{b}}$ \\
P7+R.s & $68.98 \pm 1.27^{\mathrm{a}}$ & $4.53 \pm 0.91^{\mathrm{d}}$ \\
R.s & $71.06 \pm 0.91^{\mathrm{a}}$ & - \\
\hline
\end{tabular}

Mean followed by the same letter within a column are not significantly different as determined by the LSD test $(\mathrm{p}<0.05)$ 


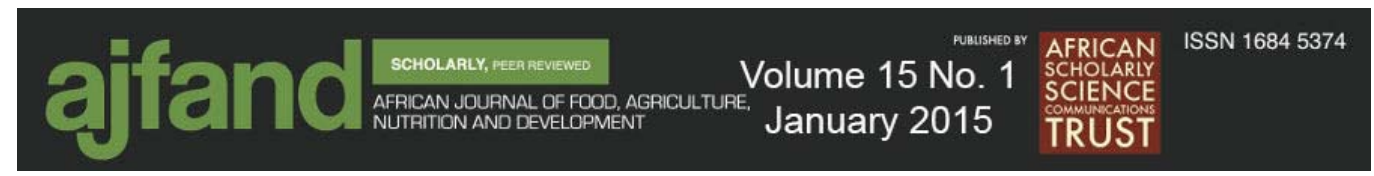

Table 3: Effect of application of antagonistic bacterial isolates and Ralstonia solanacearum on the height and weight of fresh and dried potato plants

\begin{tabular}{|c|c|c|c|c|c|c|}
\hline \multirow[t]{2}{*}{ Treatment } & \multicolumn{2}{|c|}{ Fresh shoot biomass (g) } & \multicolumn{2}{|c|}{ Dry shoot biomass (g) } & \multicolumn{2}{|c|}{ Plant height (cm) } \\
\hline & Mean & GPE (\%) & Mean & GPE (\%) & Mean & GPE (\%) \\
\hline E7+R.s & $5.91 \pm 0.25^{\mathrm{d}}$ & 13.87 & $2.05 \pm 0.06^{\mathrm{c}}$ & 21.33 & $52.11 \pm 1.57^{b}$ & 24.24 \\
\hline E13+R.s & $8.75 \pm 0.48^{a}$ & 68.75 & $3.64 \pm 0.43^{\mathrm{a}}$ & 115.42 & $60.66 \pm 1.27^{\mathrm{a}}$ & 44.63 \\
\hline S25+R.s & $9.11 \pm 0.13^{\mathrm{a}}$ & 75.85 & $3.15 \pm 0.09^{b}$ & 86.17 & $60.75 \pm 1.28^{\mathrm{a}}$ & 44.84 \\
\hline P7+R.s & $3.94 \pm 0.28^{f}$ & - & $1.84 \pm 0.13^{\mathrm{c}}$ & 8.92 & $48.66 \pm 0.96^{c}$ & 16.02 \\
\hline R.s & $5.18 \pm 0.36^{\mathrm{e}}$ & - & $1.69 \pm 0.09^{d}$ & - & $41.94 \pm 1.14^{\mathrm{e}}$ & - \\
\hline Saline solution & $6.77 \pm 0.19^{c}$ & - & $2.97 \pm 0.09^{\mathrm{b}}$ & - & $46.01 \pm 0.77^{\mathrm{d}}$ & - \\
\hline
\end{tabular}

Mean followed by the same letter within a column are not significantly different as determined by the LSD test $(p<0.05)$; Data represent means of the experiment with four replications each.

GPE: Growth Promotion Efficacy

R.s: Ralstonia solanacearum 


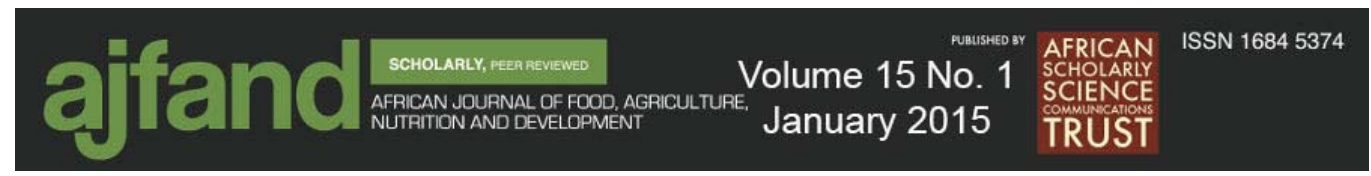

\section{REFERENCES}

1. Hayward AC Ralstonia solanacearum. In: Encyclopedia of Microbiology. J. Lederberg, ed. Academic Press, San Diego, CA. 2000.

2. Crawford DL, Lynch JM and MA Ousley Isolation and characterization of actinomycetes antagonists of a fungal root pathogen. Appl. Environ. Microbiol. 1993; 59 (11): 3899-3905.

3. Curl EA and B Truelove The rhizosphere. Advanced Series in Agriculture Sciences, 15. Springer-Verlag Berlin Heidelberg. 1986; 288 pp.

4. Kelman A The relationship of pathogenicity in Pseudomonas solanacearum to colony appearance on tetrazolium medium. Phytopathol. 1954; 44:693-695.

5. Zubeda $\mathbf{C}$ and $\mathbf{R}$ Hamid Isolation and characterization of Ralstonia solanacearum from infected tomato plants of soanskesar valley of punjab. Pak. J. Bot. 2011; 43(6): 2979-2985.

6. Denny TP Plant pathogenic Ralstonia species. In: Bacteria SS and Gnanamanickam (Ed). Plant-Associated, Springer Publishing, Dordrecht, The Netherlands. 2006: 573-644.

7. Opina N, Tavner F, Hollway G, Wang JF, Li TH, Maghirang R, Fegan M, Hayward AC, Krishnapillai V, Hong WF, Holloway BW and JN Timmis A novel method for development of species and strain specific DNA probes and PCR primers for identifying Burkholderia solanacearum (formely Pseudomonas solanacearum). Asi. Pac. Mol. Biol. Biotechnol. 1997; 5: 19-30.

8. King EO, Ward MKM and DE Raney Two simple media for the demonstration of pyocyanin and fluorescein. J. Lab. Clin. Med. 1954; 44: 301 307.

9. Fisher PJ, Petrini O and HM Lappin-Scott The distribution of some fungal and bacteria endophytes in maize (Zea mays L.). New. Phytol. 1992; 122: 299305 .

10. Kuster $\mathbf{E}$ and ST Williams Selection of media for isolation of Streptomycetes. Nat. 1964; 202: 928-929.

11. Oskay M, Usame A and C Azeri Antibacterial activity of some actinomycetes isolated from farming soils of Turkey. Afr. J. Biotechnol. 2004; 3: 441-446.

12. Almoneafy AA, Xie GL, Tian WX, Xu LH, Zhang GQ and M Ibrahim Characterization and evaluation of Bacillus isolates for their potential plant growth and biocontrol activities against tomato bacterial wilt. Afr. J. Biotechnol. 2012; 11(28): 7193-7201. 


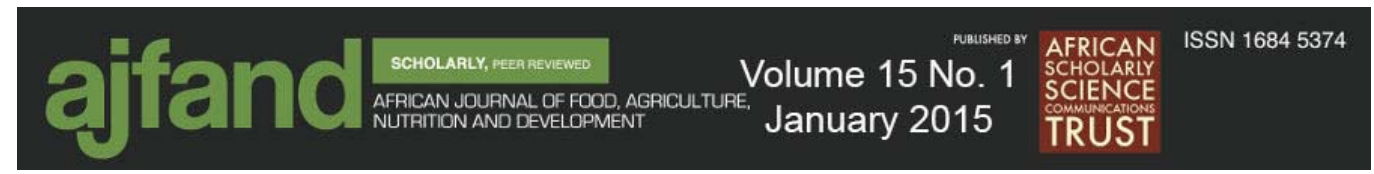

13. Park EJ, Lee SD, Chung EJ, Lee MH, Um HY, Murugaiyan S, Moon BJ and SW Lee Microtom- a Model Plant System to Study Bacterial Wilt by Ralstonia solanacearum. Plant Pathol. J. 2007; 23(4): 239-244.

14. Xue QY, Chen Y, Li SM, Chen LF, Ding GC, Guo DW and JH Guo Evaluation of the Strains of Acinetobacter and Enterobacter as Potential Biocontrol Agents against Ralstonia Wilt of Tomato. Biol. Control. 2009; 48(3): 252-258.

15. Shirling EB and D Gottlieb Methods of characterization of Streptomyces species. Int. J. Sys. Bacteriol.1996; 16: 313-349.

16. Locci R Streptomyces and related Genera. In: Bergey's Manual of Systematic Bacteriology. Williams \& Wilkins Company, Baltimore. 1989; 4: 2451-2508.

17. Buysse W, Stern $\mathbf{R}$ and $\mathbf{R}$ Coe Genstat Discovery Edition for everyday use. ICRAF editor. Nairobi, Kenya. 2004.

18. Prunier JP Différenciation en types biochimiques de souches de Pseudomonas solanacearum (Smith) Smith. Phitiat. Phytophar. 1967; 16: 199-204.

19. Lallmahomed GM, Rakotobe $\mathbf{R}$ and Rakotondramanana Biovars and races of Pseudomonas solanacearum in Madagascar - a preliminary study. FAO Plant. Prot. Bill. 1988; 36(2): 54-59.

20. El Albyad MS, el Sayed MA and AR el Shanshoury Effect of culture conditions on the antimicrobial activities of UV-mutants of Streptomyces corchorusii and Streptomyces spiroverticillatus against bean and banana wilt pathogens. Microbiol. Res. 1996; 151:201-211.

21. Guo JH, Guo YH, Zhang LX, Qi HY and ZD Fang Screening for biocontrol agents against cayenne pepper bacterial wilt. Chi. J. Biol. Control. 2001; 17:101-106.

22. Götz M, Gomes NCM, Dratwinski A, Costa R, Berg G, Peixoto R, Mendonça-Hagler $\mathbf{L}$ and $\mathbf{K}$ Smalla Survival of gfp-tagged antagonistic bacteria in the rhizosphere of tomato plants and their effects on the indigenous bacterial community. FEMS Microbiol. Ecol. 2006; 56: 207-218.

23. Lemessa $\mathbf{F}$ and $\mathbf{W}$ Zeller Screening Rhizobacteria for Biological Control of Ralstonia solanacearum in Ethiopia. Biol. Control. 2007; 42(3): 336-344.

24. Trejo-Estrada SR, Rivas SI and D L Crawford In vivo and In vivo Antagonism of Streptomyces violaceusniger YCED9 against Fungal Pathogens of Turfgrass. World. J. Microbiol. Biotechnol. 1998; 14: 865-827.

25. Weller DM 1988. Biological-Control of Soilborne Plant-Pathogens in the Rhizosphere with Bacteria. Ann. Rev. Phytopathol. 1988; 26: 379-407. 


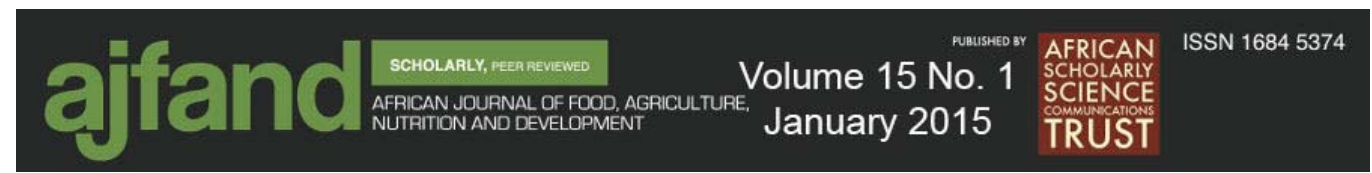

26. Manulis S, Shafrir H, Epetein E, Lichter A and I Barash Biosynthesis of indole-3-acetic acid via indole-3-acetamide pathway in Streptomyces spp. Microbiol. 1994; 140: 1045-1050.

27. Igarashi Y, T Iida R, Yoshida and T Furumai Pteridic acids A and B, novel plant growth promoters with auxin-like activity from Streptomyces hygroscopicus TP-A0451. J. Antibiot. 2002; 55: $764-767$.

28. Ran LX, Liu CY, Wu GJ, Van Loon LC and PAHM Bakker Suppression of bacterial wilt in Eucalyptus urophyllaby fluorescent Pseudomonas spp. in China. Biolog. Control. 2005; 32: 111-120.

29. Lechevalier HA The Actinomycetes III, A Practical Guide to Generic Identification of Actinomycetes. In: Bergey's Manual of Systematic Bacteriology. Williams \& Wilkins Company, Baltimore. 1989; 4: 2344-2347.

30. Anderson AS and MHE Wellington The taxonomy of Streptomyces and related genera. Int. J. Syst. Evol. Microbiol. 2001; 51: 797-814. 